Article

\title{
Earnings Persistence of European Football Clubs under UEFA's FFP
}

\author{
Panagiotis E. Dimitropoulos * and Konstantinos Koronios \\ Department of Sport Organization and Management, University of Peloponnese, Sparta 23100, Greece; \\ konskoron@hotmail.com \\ * Correspondence: dimitrop@uop.gr; Tel.: +30-273-108-9677
}

Received: 4 March 2018; Accepted: 13 April 2018; Published: 17 April 2018

\begin{abstract}
The goal of this study was to examine the predictability and persistence of earnings of the European football clubs and whether the new Union of European Football Associations (UEFA) Financial Fair Play (FFP) licensing regulation has forced clubs to produce a more predictable earnings stream. We utilized a sample of 109 European top-tier clubs over the period 2008-2016, summing up to 844 firm-year observations. Empirical evidence indicated that the cash flow component of earnings is more relevant in predicting one-year ahead earnings than accruals. This positive impact of cash flows for predicting earnings is more significant after the FFP regulation since earnings predictability has increased during that period. Moreover, the abovementioned finding is more significant for the smaller league clubs rather than the Big-5 league clubs. This finding is attributed to the fact that smaller league clubs are more in need of UEFA prize money relative to Big-5 league clubs, thus they are more incentivized to produce a more predictable earnings stream.
\end{abstract}

Keywords: earnings persistence; accruals; earnings predictability; European football clubs; financial fair play

JEL Classification: M41; G32; G34

\section{Introduction and Theoretical Background}

The professionalization of European football has been considered by academics, practitioners and regulators for several years now, especially since clubs have been transformed to well establish corporations with separate ownership and control (Andreff 2007) and some of them have been floated on the stock exchange. Clubs have managed to attract significant amounts of revenues from several sources, not only the classic match day receipts, but also from sponsoring, advertising, merchandising, broadcasting contracts, league prizes, etc. Nevertheless, the financial viability of the majority of European clubs has been deteriorating significantly for several years leading to accumulated debt and losses, despite the increased revenue streams and amounts invested on behalf of the shareholders (Dermit-Richard et al. 2017).

These are the symptoms of clubs' financial instability yet the actual culprit lies within the operational framework of the clubs and their relation to their fans and other stakeholders. Dimitropoulos et al. (2016) argud that clubs establish close relationship with their fans and in several instances fans affect managers' decisions. Fans cannot be considered as customers since they are emotionally attached to the club and even intervene to assist clubs when financial troubles knock at their door. Moreover, fans exert significant pressure on managers to enhance athletic success, and, therefore, to achieve higher on-field performance, managers are willing to pay exorbitant salaries and transfer fees for improving club's roster competitiveness. Thus, a club's relation with fans is one source of financial irrationality but is not the only one faced by clubs. Furthermore, Mourao (2012) verified 
the abovementioned arguments suggesting that clubs in Europe face a triangle of behavioral forces that does not let them escape from indebtedness. The triangle is formed by the pressure of athletic success, football players' increased wages (attributed to the pressure for on-field success) and media coverage which exerts the biggest portion of revenues. Football player wages have increased over the years such that more than 50-60 percent of clubs' revenues are channeled to cover player wages (Nicoliello and Zampatti 2016). This wage inflation trend is exacerbated by the majority of leagues in the European continent. According to Rohde and Breuer (2016), the pursuit of higher on-field performance is achieved via paying increasing player transfer fees and wage contracts and on-field success contributes to higher revenues from league prizes and media coverage. However, the goal of athletic success is not always achieved, bestowing on the investment in player transfers high risk, leading to a deterioration of soccer quality and an increase in costs and debt levels.

The issue of financial vulnerability and indebtedness has been on the agenda of the UEFA and the issuance of the financial fair play regulation (FFP) aimed at the rationalization of club finances. The financial principles of the FFP are not distant from the common logic of financial sustainability: (a) debt must be kept within manageable levels and paid on time; and (b) expenditure must be kept within the parameters of each club's ability to pay based on their revenues (Cordery et al. 2013). Practically, UEFA introduced profitability as the most important financial characteristic of the new licensing regulation since clubs have to prove that they will honor their debt obligations (no overdue payables). According to Nicoliello and Zampatti (2016), clubs need to reduce the cost side of the equation (player and staff wages) or increase revenues to achieve profitability. Moreover, several clubs in both major and minor European Leagues are operating in the "red" since descriptive evidence from the sample of the current study indicate that the average shareholder's funds are negative and up to -5.9 percent of total assets, over the period 2008-2016. Practically, 30 percent of our observations have negative equity and this fact corroborates previous arguments in the above-mentioned literature regarding the insolvency of European football clubs.

Within this framework, the current study aimed to examine whether the new FFP regulation has impacted on clubs' motives to produce a more reliable and sustainable earnings stream to achieve future profitability and adhere to the new regulatory guidelines. Earnings persistence is a crucial characteristic of earnings quality since, according to Kang et al. (2012), the role of financial reporting is to provide useful information to investors for assessing future cash flows and earnings, thus is a very useful attribute for financial decision making. Practically, earnings persistence expresses the extent that present profits may be maintained in the future. This was estimated by a regression of future earnings on current earnings. The closer the regression coefficient was to unity (1), the higher was the earnings persistence. Studies by Sloan (1996), Richardson et al. (2005), and Oei et al. (2008) in samples of American and Australian firms estimated an earnings persistence coefficient ranging from 0.609 in Australia to 0.84 in the US. This is interpreted as, if a company earns $\$ 1$ of earnings during year $t$, then $\$ 0.84$ would be expected to persist in the following year $t+1$. In other words, earnings figures of firms with higher earnings persistence are more predictable (thus those firms are associated with lower information uncertainty) and is consequently easier for investors and regulators to assess the future status of the firm.

The consensus among financial economists is that the improved quality of financial numbers produces advantages such as better allocation of resources, higher liquidity to the markets and firms, a reduction of cost of capital, and lower information asymmetry (Kothari et al. 2009). Those findings suggest that earnings that map closely into cash are more favorable, are more persistent and can help investors to predict future earnings. Since investors are relying on earnings to make investment decisions to a higher extent than cash flows and dividends, if earnings are of poor quality, they will reduce the coordination between firms and their stakeholders, creating information risk. This in turn will lead investors to demand a higher risk premium for their investments, contributing to increased cost of capital (Francis et al. 2004). This fact was corroborated by Rascher et al. (2012) in the NFL. They argued that clubs with volatile or unpredictable revenues face increased cost of debt, since the desired 
uncertainty in sport outcomes has the consequence of reducing the predictability of revenue streams, leading to more information asymmetry and thus to increased cost of capital. Nevertheless, investment in new stadia reduces this information asymmetry and leads to more predictable revenue streams. Even though the study of Rascher et al. (2012) focused on revenues and not profits, it provided a useful example of the positive impact of persistence on corporate attributes such as financial risk.

Earnings persistence is even more important for economic sectors that face significant regulatory changes (Kang et al. 2012). Altamuro and Beatty (2010) and LaFond and You (2010) provided analyses of regulatory change in the US banking industry (the FDICIA internal control regulation) arguing that, when regulation is formatted out of a crisis and this regulation reforms and enhances corporate supervision and imposes stricter financial reporting requirements, it impacts on the predictability and persistence of firm earnings. Especially in the US banking industry, this new regulatory intervention increased the predictability of banks' cash flows and earnings persistence, and reduced income smoothing for those banks that were obliged to comply with the new regulation. The football industry and the new FFP regulation share several common characteristics with the abovementioned study. UEFA introduced more strict criteria (not only financial but also strong merit is attributed to financial criteria) for granting licenses to prestigious leagues (Champions League and Europa League). Moreover, the Club Financial Control Body (CFCB) was established as an additional mechanism for examining the reliability of clubs' financial reports and assessing the effectiveness of clubs achieving the FFP criteria and whether they comply with the designated regulation. Overall, the new FFP regulation increased scrutiny placed on football clubs and undoubtedly increased club monitoring and oversight.

To examine whether the FFP regulation has improved clubs' earnings persistence, we utilized a sample of 109 European top-tier clubs over the period 2008-2016. Empirical evidence indicated that the cash flow component of earnings is more relevant in predicting future earnings than accruals. This positive impact of cash flows for predicting earnings is more significant after the FFP regulation since earnings predictability increased during that period. Moreover, the abovementioned finding is more significant for the smaller league clubs rather than the Big- 5 league clubs. This finding is attributed to the fact that smaller league clubs are more in need of UEFA prize money relative to Big-5 league clubs (Menary 2016) because UEFA prize money constitutes a larger part of their annual revenues. Thus, they are more incentivized to produce a more predictable earnings stream.

This study adds to a growing literature on earnings persistence within an industry facing severe financial problems. A recent study by Dermit-Richard et al. (2017) showed that, in France, clubs' budget is targeting towards funding losses (by 74 percent) instead of investments. This fact accords with the issue that shareholders' contributions do not suffice to cover losses (for the majority of top-tier clubs), leading clubs to disinvest or downsize business activities, creating a volatile economic environment. FFP regulation aims to mitigate these problems by forcing clubs to live on their own resources and sustain their viability. Thus, this study provided ample evidence of the impact of the new regulation on the tendency of football clubs to focus on a medium to long term policy towards profitability, thus enhancing their financial reporting quality as a way to sustain their participation in UEFA's lucrative championships.

The rest of the paper is organized as follows: Section 2 is devoted to the literature review and the formation of the research hypotheses. Section 3 presents the data selection procedure and the research design. Section 4 discusses the empirical results of the study and related sensitivity analysis. Section 5 concludes the paper, offering useful policy implications for clubs and regulators and potential avenues for future research.

\section{Related Literature and Research Hypotheses}

As previously mentioned, a crucial role of the financial accounting reporting system is to serve as a mechanism to signal firms' future performance to the public and also to discipline managerial behavior (Kang et al. 2012). Nevertheless, financial accounting follows the accrual principle for 
recognizing revenues and expenses ${ }^{1}$, a fact that helps portray more effectively firms' actual financial condition, yet it has the disadvantage of greater subjectivity on the estimation of several accounting figures (provisions, depreciation, inventories, etc.). As Richardson et al. (2005) mentioned, if accrual accounting were not in effect, the only asset or liability that would appear on a firm's balance sheet would be the cash asset amount. Put differently, all other assets and liabilities on the balance sheet are the outcome of the accrual accounting process (Oei et al. 2008).

Under this framework, previous studies on the issue of accruals persistence indicated that accruals are less persistent than cash flows due to the increased subjectivity of accruals relative to cash flows and also because accruals can easily be manipulated with less material impact on the firms' fundamentals, relative to cash flows (Sloan 1996). The reduced persistence of accruals is also attributed to their lower reliability because accruals require judgments for the estimation of the relative figures, and even in the case of no manipulation of those figures, they definitely contain errors that will be corrected in accruals recorded in future periods. Earnings persistence (as a measure of earnings informativeness) does not suffer from the potential measurement errors inherent in accrual models and is characterized as an important feature of financial reporting integrity and firm value (Kormendi and Lipe 1987; Kang et al. 2012).

These types of errors could be the estimating outcome of future economic effects of current or past transactions which are measured with error (Oei et al. 2008). For example, the provision or allowance for doubtful debt will never be completely accurate. In addition, in the European football industry, UEFA's (2015) FFP regulation declares that, for the estimation of the clubs' relevant revenues (for those clubs which follow the capitalization and amortization method), the profit from disposal of player registration rights is calculated by deducting the net book value at the time of the transfer from the net disposal proceeds received or receivable. This means that clubs generate large accrual accounting from player registration rights which are not always received in total due to other arrangements ${ }^{2}$, creating errors in the estimation.

Furthermore, Dermit-Richard et al. (2017) argued that several determinant figures of the relevant revenues and expenses which come from related parties must be adjusted to reflect the fair value of such transactions. For instance, sponsorship deals must be evaluated at fair values yet those might not be comparable to other respective deals for other clubs, so they are inherent to enhanced subjectivity by managers. The main issue here is the input information that clubs use to estimate those fair values. If the information come from verifiable sources, then subjectivity is diminished (not eliminated), but, if information is derived from non-verifiable sources and includes more judgment on behalf of the club management, then accruals are definitely estimated with error. Consequently, following the previous discussion, due to the measurement error in accruals, the persistence coefficient on the accrual component should be smaller than the persistent coefficient on the cash flow component of earnings due to less or no error in tis measurement. Thus, the first research hypothesis is stated as follows:

H1: Accruals will be less persistent than cash flows.

Previous studies on the impact of regulatory intervention on earnings persistence provided ample but contradictory evidence. For instance, Kang et al. (2012) indicated that the abolition of the 20-F reconciliation requirement for firms cross-listing in the US was not improved for all firms but only for those that were originating from weak investor protection countries. This fact was explained as 20-F reconciliation playing a signaling role for the financial statement users and its elimination led to an increase in firms' incentives to improve the reporting quality voluntarily. Additionally, LaFond and You (2010) argued that the introduction of the Federal Deposit Insurance Corporation Improvement Act (FDICIA) as a response of the US government to the 2007-2008 financial crisis, imposed stricter

1 Revenues and expenses are recognized when they are materialized, irrespectively of the time of payment.

2 For example, several clubs re-arrange those deals by lending players to each other for a short-period, a fact which does not affect cash assets. 
reporting requirements such as the disclosure of the fair market values of bank assets. This legislation increased the supervision of banks imposing annual on-site inspections on banks and the formation of an independent audit committee. Relative interventions were imposed on those banks that failed to meet the respective requirements of the law. Practically, the new regulation forced management to report their responsibilities for preparing financial statements, sustaining an adequate internal control structure and conform to laws and regulations. According to Altamuro and Beatty (2010), this regulation increased banks earnings persistence and earnings predictability due to increased monitoring and oversight, which contributed to less reporting discretion. This reduced managerial discretion increased the association between current reported accruals and future cash flows.

The financial fair play (FFP) regulation in European football shares several common features relative to the above-mentioned cases. The new UEFA regulation increased the amount of financial information that clubs have to publish, introduced greater scrutiny on clubs' finances via the financial oversight board, and dictated that national football federations must exercise additional control on clubs' operations. Failure of clubs to adhere to the new regulations would lead to sanctions, in the form of transfer restrictions, refusing to grant licenses, cash fines, withholding prizes and several other measures. This new environment impacts clubs' financial reporting decisions since the failure to conform to the new regulation definitely impacts clubs' future athletic success and financial performance. Thus, clubs are more incentivized to report earnings that are more stable and predictable in the future. Therefore, the second hypothesis is stated as follows:

H2: Earnings persistence has increased after the FFP regulation implementation.

Moreover, regulatory changes are expected to have a different impact on earnings persistence between smaller and larger firms, belonging to different size markets. LaFond and You (2010) indicated that, after the FDICIA regulation in the US banking industry, smaller banks experienced larger increases in earnings persistence and predictability, a result attributed to the increased motivation by managers of smaller banks to signal their financial statement quality in the market and mainly because any negative outcome regarding non-compliance with the new regulation would result in severe or unaffordable implications relative to larger banks. In addition, Kang et al. (2012) documented that the level of investor protection mechanisms in a market directly impacts the reporting incentives. For example, in a market where there is more regulation on the reporting system and decisions are more transparent (thus protecting the interests of shareholders and various stakeholders), there is less incentive for those firms to enhance their earnings predictability due to the smaller marginal benefit that they receive from this behavior. On the contrary, firms in countries with smaller firms and markets (and less investor protection mechanisms) are more incentivized to voluntarily improve their reporting quality to gain access to financing.

Following the above-mentioned reasonin, $g$ the size of the leagues and hence the teams is expected to have an effect on the persistence of earnings. Specifically, smaller clubs gain a significant percentage of their annual budget (and revenues) from UEFA prizes. According to Solberg and Haugen (2010), Swedish clubs increased their revenues by almost 80 percent in the case that they were qualified to the first round of Europa League or Champions League. The same situation stands for other small European Leagues (Cyprus, Bulgaria, Greece, etc.) where, according to Menary (2016), the adherence of small clubs to the FFP can yield significant revenues able to finance the club's budget and even achieve club's sustainability. On the contrary, clubs from larger leagues (such as the Top-5 championships) are not so dependent on UEFA prizes since they present a balance between revenues from their national league and UEFA tournaments (Menary 2016). Consequently, based on the above discussion, clubs from smaller leagues are expected to report more persistent earnings figures to enhance their reliability towards the financial control body and also their chances to adhere to the new regulatory requirements, relative to clubs from larger leagues. However, the opposite reasoning can also be true since larger clubs might lose more if they fail to conform to FFP regulation, since they are more likly to advance their presence in the prestigious UEFA tournaments and gain more revenues. Thus, due to 
the conflicting arguments mentioned above, the third and final hypothesis is formed in the null form as follows:

H3: There will be a difference on the earnings persistence between smaller and larger league clubs.

\section{Data Selection and Research Design}

The sample selection procedure included the selection of financial accounting data, namely net profit, operating cash flows and total assets from the annual financial statement from clubs in European countries (Belgium, Finland, France, Greece, Italy, Netherlands, Norway, Spain, and United Kingdom) that had at least two football clubs with available financial data for more than two fiscal years over the period 2008-2016. The sample selection started by collecting data from 117 football clubs which fit the legal form of a corporation, however we had to delete six clubs due to data unavailability. Moreover, to reduce the impact of outliers and thus eliminate potential biases in the estimation of the variables, we removed the upper and lower 1 percent of the data distribution of earnings and cash flows. Consequently, the final unbalanced sample includes 109 football clubs and 869 firm year observations. Table 1 presents the distribution of our sample clubs per country. The majority of the sample observations originated from the Big- 4 championships, namely United Kingdom, Italy, France, and Spain. Greece presented a significant portion of the sample observations followed by Belgium. The fact that Big-4 leagues constituted the majority of our sample observations warranted the examination of earnings persistence between Big-4 and Non-Big-4 leagues, as discussed in Section 4 .

Table 1. Observations distribution per country and year.

\begin{tabular}{ccccccccccc}
\hline Countries & $\mathbf{2 0 0 8}$ & $\mathbf{2 0 0 9}$ & $\mathbf{2 0 1 0}$ & $\mathbf{2 0 1 1}$ & $\mathbf{2 0 1 2}$ & $\mathbf{2 0 1 3}$ & $\mathbf{2 0 1 4}$ & $\mathbf{2 0 1 5}$ & $\mathbf{2 0 1 6}$ & Total \\
\hline Belgium & 7 & 7 & 6 & 7 & 6 & 6 & 5 & 7 & 7 & 58 \\
Finland & 2 & 1 & 1 & 2 & 2 & 1 & 2 & 2 & 2 & 15 \\
France & 11 & 11 & 11 & 11 & 11 & 11 & 10 & 11 & 11 & 98 \\
Greece & 10 & 10 & 9 & 10 & 10 & 10 & 10 & 10 & 10 & 89 \\
Italy & 20 & 19 & 18 & 20 & 20 & 20 & 20 & 20 & 20 & 177 \\
Netherlands & 3 & 3 & 3 & 3 & 3 & 3 & 3 & 3 & 3 & 27 \\
Norway & 2 & 2 & 2 & 2 & 2 & 2 & 1 & 1 & 1 & 15 \\
Spain & 6 & 7 & 7 & 7 & 7 & 7 & 7 & 7 & 7 & 62 \\
United & 37 & 37 & 37 & 37 & 37 & 37 & 29 & 43 & 43 & 328 \\
Kingdom & 98 & 97 & 92 & 97 & 96 & 94 & 87 & 104 & 104 & 869 \\
Total & 9 & & & & & & & & & \\
\hline
\end{tabular}

The final sample exclusively included football clubs that participate in the top division of their country's official league (as in Dimitropoulos et al. 2016) for two main reasons: those clubs competing in the top division of the national league are more likely to participate in UEFA championships and therefore are more inclined to conform to the criteria set by the FFP regulation. Thus, we expect that they are more motivated to report more persistent earnings figure to improve their chances to adhere to the new regulation's financial criteria.

Our research design required dividing the sample into two sub-periods: the pre-FFP implementation period (including fiscal years ending in June 2008-2011) and the post-FFP period (fiscal years ending in June 2012-2016). The reason for selecting 2012 as the beginning of the FFP-period (even though the regulation was first published in 2010) is because the 2011-2012 football season (and fiscal year) is the first during which the FFP regulation was in full force. Practically, the implementation of the FFP regulation was not in full effect during (and before) the fiscal year ending June 2011, since several exemptions and acceptable levels of deviation were imposed from the regulation's financial criteria to assist clubs to steadily adjust to the new regulatory environment. Therefore, we considered the 2011 fiscal year belonging to the pre-FFP regulation period to draw more precise inferences regarding the impact of the new regulation on earnings persistence. 
We measured earnings persistence by regressing the future return on assets on the current return on assets following previous studies by Richardson et al. (2005) and Oei et al. (2008) according to the following model:

$$
R O A_{i t+1}=a_{0}+a_{1} R O A_{i t}+e_{i t}
$$

where $R O A$ is the return on assets estimated as net income after tax to lagged total assets and $e$ is the regression error term. Subscripts $i$ and $t$ denote the club and the year, respectively. Model (1) was estimated including club fixed effects to capture any impact on the regression model attributed to specific club characteristics. Model (1) was estimated using the panel fixed effect estimation since panel analysis contains more information with more variability and less collinearity among the variables, leading to more efficient estimates and precise parameters of model estimation, allowing us to detect many effects that are not detectable in plain cross-sectional data analysis. In addition, we performed the Breusch-Pagan Lagrangian multiplier test for random effect, which tests the null hypothesis that the error variance is equal to zero. The test produced an insignificant value leading us not to reject the null and thus the fixed effect estimation is considered as the most appropriate estimation method. Coefficient $a_{1}$ measures earnings persistence, and the closer to unity (1), the higher the earnings persistence, indicating a more stable and predictable earnings stream.

The first hypothesis states that the accrual component of earnings will be less persistent than cash flow component of earnings in the determination of future earnings. To test this hypothesis, we estimated the following equation to capture the differential persistence of the accrual components of earnings:

$$
R O A_{i t+1}=\beta_{0}+\beta_{1} R O A_{i t}+\beta_{2} T A C C_{i t}+e_{i t}
$$

where TACC denotes the club's total accruals estimated as the different between net income and operating cash flows divided by lagged total assets. The rest of the variables are defined as above.

According to Richardson et al. (2005), the accrual component of earnings is expected to be less persistent than the cash flow component of earnings, which is the difference between earnings performance and the accrual component of earnings performance. Thus, the initial functional form of Model (2) was as follows:

$$
R O A_{i t+1}=\gamma_{0}+\gamma_{1}\left(R O A_{i t}-T A C C_{i t}\right)+\gamma_{2} T A C C_{i t}+u_{i t+1}
$$

where $\gamma_{1}$ capture the persistence of cash flows and $\gamma_{2}$ captures the persistence of accruals. Thus, the modified version Model (2a) is Model (2) with earnings performance itself instead of cash flow performance. Rewriting Equation (2a) in terms of the persistence parameters produced the following:

$$
R O A_{i t+1}=\gamma_{0}+\gamma_{1} R O A_{i t}+\left(\gamma_{2}-\gamma_{1}\right) T A C C_{i t}+u_{i t+1}
$$

Thus, $\beta_{1}=\gamma_{1}$ and $\beta_{2}=\left(\gamma_{2}-\gamma_{1}\right)^{3}$. According to Richardson et al. (2005), the advantage of estimating Model (2) instead of Model (2b) is that $\beta_{2}$ provides a direct estimate of $\left(\gamma_{2}-\gamma_{1}\right)^{4}$.

Model (2) was estimated including club fixed effects to capture any impact on the regression model attributed to specific club characteristics. For example, there could be small differences in the revenues sharing process between leagues. A recent report by KPMG (2017) indicated that the Big-5 European leagues present a somehow uniform process of broadcasting revenue distribution with the majority of revenues being shared equally between clubs, and an equal percentage is distributed based on sport performance and popularity. This form of distribution is evidenced in other minor leagues as well such as Greece. The relative distribution percentages of each factor may differ from league

3 Please refer to the study by Richardson et al. (2005), Section 4.2 for the derivation of this formula.

4 We estimated Model $(2 \beta)$ as well, but untabulated results provide qualitatively similar findings compared with those on the main tables, so we discuss the results from the estimation of Model (2). 
to league so the club fixed effect aims to capture this impact. In Equation (2), coefficient $\beta_{1}$ captures the persistence of the cash flow component of earnings, while coefficient $\beta_{2}$ captures the differential persistence of the accrual component of earnings. If $\mathrm{H} 1$ is valid, we expect coefficient $\beta_{2}$ to be smaller in magnitude and significance relative to coefficient $\beta_{1}$.

To examine the second research hypothesis, Models (1) and (2) were reestimated during the pre (2008-2011) and post (2012-2016) FFP regulation sub-periods. If H2 is valid, we expect a highly significant and positive coefficient with larger magnitude during the post-FFP period relative to the pre-FFP period. Finally, to examine the third research hypothesis, both models were reestimated after partitioning the sample between sample clubs belonging to the top European leagues (Italy, France, Spain and UK) and clubs belonging to the other European leagues. H3 is verified if coefficient $\beta_{1}$ is larger in magnitude and significant for Non-Top-4 leagues relative to Top-4 leagues.

\section{Empirical Results}

Table 2 presents the descriptive statistics of the main variables for the whole research period, as well as during the pre- and post-FFP periods. The average total accruals are negative and cover 17 percent of total assets, indicating that net income is less than cash flows for the sample clubs, thus clubs operate with more accruals on their profit and loss account. In addition, average return on assets is negative and covers 10 percent of total assets. This result is relevant to previous studies on European football regarding the clubs' financial performance (Dimitropoulos et al. 2016). Average ROA does not present any significant change before and after the implementation of FFP regulation, while, on the contrary, TACC have been reduced after FFP initiation from -0.18 to -0.16 , indicating the tendency of clubs to report accounting earnings that are more associated with operating cash flows.

Table 2. Descriptive statistics of sample variables.

\begin{tabular}{ccc}
\hline Variables & TACC & ROA \\
\hline FULL SAMPLE & & \\
Mean & -0.169 & -0.101 \\
St.Dev. & 0.241 & 0.417 \\
Min & -1.355 & -2.859 \\
Max & 3.641 & 4.854 \\
\hline PRE-FFP & & \\
Mean & -0.180 & -0.102 \\
St.Dev. & 0.205 & 0.475 \\
Min & -1.355 & -2.859 \\
Max & 0.281 & 4.854 \\
\hline POST-FFP & & \\
Mean & -0.160 & -0.100 \\
St.Dev. & 0.267 & 0.365 \\
Min & -1.339 & -2.784 \\
Max & 3.641 & 2.090 \\
\hline
\end{tabular}

The sample period includes fiscal years from 2008 to 2016. The pre-FFP period is 2008-2011 and the post-FFP period is 2012-2016. TACC is total accruals estimated as the different between net income and operating cash flows divided by lagged total assets, and ROA is the return on assets estimated as net income after tax to lagged total assets.

Table 3 presents the estimation of regression Model (1) for the whole period under investigation as well as during the pre- and post-FFP periods. Overall, earnings persistence is 0.183 , suggesting that on average from a $€ 1$ profit during the current year 0.18 cents are expected to persist in the following year. This coefficient is far below the persistence coefficient of previous studies in the US, Australia and Korea (Richardson et al. 2005; Oei et al. 2008; Jeon et al. 2006). This result can be attributed to the increased volatility of football clubs' profits and revenues, as evidenced by Rascher et al. (2012), and the fact that several clubs in Europe do not focus on sustaining their profitability but just breaking 
even (Dermit-Richard et al. 2017). Nevertheless, the coefficient on earnings persistence is higher in magnitude and statistically significant only in the post-FFP period (0.296) indicating that almost $€ 0.30$ of current earnings will persist in the following year. The coefficient of ROA during the pre-FFP period is positive, yet not statistically significant within conventional levels. Taken together, findings in Table 2 verify $\mathrm{H} 2$ and indicate that the new UEFA regulation increased the amount of financial information that clubs have to publish, and introduced greater scrutiny on clubs finances via the financial oversight board, and this impacted clubs' financial reporting decisions, leading them to report earnings that are more persistent and predictable in the future.

Table 3. Earnings persistence results.

\begin{tabular}{|c|c|c|}
\hline Variables & Coef. & $\begin{array}{c}T \text {-Test } \\
(p \text {-Value })\end{array}$ \\
\hline \multicolumn{3}{|c|}{ FULL SAMPLE } \\
\hline Constant & $-0.083^{* * *}$ & $\begin{array}{c}-6.44 \\
(0.001)\end{array}$ \\
\hline $\mathrm{ROA}$ & $0.183^{* *}$ & $\begin{array}{c}2.22 \\
(0.026)\end{array}$ \\
\hline $\mathrm{R}^{2}$-Adj. & \multicolumn{2}{|c|}{0.334} \\
\hline F-stat & $4.95^{* *}$ & $(0.024)$ \\
\hline \multicolumn{3}{|c|}{ PRE-FFP } \\
\hline Constant & $-0.107^{* * *}$ & $\begin{array}{c}-5.16 \\
(0.001)\end{array}$ \\
\hline ROA & 0.098 & $\begin{array}{c}0.93 \\
(0.520)\end{array}$ \\
\hline $\mathrm{R}^{2}$-Adj. & \multicolumn{2}{|c|}{0.115} \\
\hline F-stat & $2.87^{* *}$ & $(0.05)$ \\
\hline \multicolumn{3}{|c|}{ POST-FFP } \\
\hline Constant & $-0.059^{* * *}$ & $\begin{array}{c}-3.99 \\
(0.001)\end{array}$ \\
\hline ROA & $0.296^{* * *}$ & $\begin{array}{c}2.46 \\
(0.014)\end{array}$ \\
\hline $\begin{array}{c}\mathrm{R}^{2} \text {-Adj. } \\
\text { F-stat }\end{array}$ & \multicolumn{2}{|c|}{0.723} \\
\hline
\end{tabular}

$* * *$ and $* *$ indicate statistical significance at the $1 \%$ and $5 \%$ significance level, respectively. The sample period includes fiscal years 2008-2016. The pre-FFP period is 2008-2011 and the post-FFP period is 2012-2016. ROA is the return on assets estimated as net income after tax to lagged total assets. Club fixed effects are included in the estimation.

To verify this argument and provide an additional robustness check on the findings in Table 3, we examined whether earnings predictability enhanced after the FFP regulation came into act. For this reason, we followed previous studies by Kousenidis et al. (2013) and Gaio (2010) and estimated earnings predictability (EarnPredict) as the standard deviation of residuals of Model (1). EarnPredict measures the ability of earnings to be predicted in the future and thus be more persistent and have higher quality. Larger values of the standard deviation of residuals indicate less predictable earnings and vice versa. Therefore, we estimated a simple regression model including earnings predictability as the dependent variable and a dummy variable FFP_D (which designates the initiation of the FP regulation) acts as the independent variable. The results are presented in Table 4: 
Table 4. Earnings predictability during FFP regulation.

\begin{tabular}{ccc}
\hline Variables & Coef. & $\begin{array}{c}T \text {-Test } \\
(p \text {-Value })\end{array}$ \\
\hline \multicolumn{3}{c}{ Dependent variable: EarnPredict } \\
Constant & $0.081^{* * *}$ & 51.41 \\
& & $(0.001)$ \\
FFP_D & $-0.016^{* * *}$ & -9.32 \\
& & $(0.001)$ \\
\hline R $^{2}$-Adj. & 0.106 & \\
F-stat & $86.85^{* * *}$ & $(0.001)$
\end{tabular}

*** indicate statistical significance at the $1 \%$ significance level. The sample period includes fiscal years from 2008 to 2016. FFP_D is a dummy variable receiving unity (1) for the post-FFP period (2012-2016) and zero (0) otherwise. The dependent variable (EarnPredict) is the standard deviation of the residuals of Model (1).

The coefficient on the FFP_D variable is negative and highly significant, indicating that earnings predictability increased (the standard deviation of residuals is smaller, suggesting more predictable earnings) after the FFP implementation. The economic meaning of this coefficient is that, after the initiation of FFP regulation, the standard deviation of earnings residuals decreased by 1.6 percent suggesting enhanced earnings predictability. This finding complements the evidence in Table 3 and provides another justification for accepting $\mathrm{H} 2$.

Table 5 presents the results from the estimation of Model (2). The coefficient on the cash flow component of earnings (captured by the ROA variable) is positive and significant, while the relative coefficient of the TACC variable is insignificant, thus the cash flow component of earnings is more persistent than that of accruals, verifying H1. This finding corroborates previous evidence by Kormendi and Lipe (1987) and Kang et al. (2012) that the lower persistence of accruals is attributed to their lower reliability since accruals require judgments for the estimation of the relative figures. Moreover, the analysis during the pre- and post-FFP periods corroborates the evidence in Table 3. Specifically, the accrual component of earnings (TACC) was a significant determinant of future earnings before the FFP regulation came into act but becomes insignificant after FFP. On the contrary, the cash flow component of earnings has a positive and significant coefficient during the FFP period while the coefficient on TACC is insignificant. This evidence verifies our previously mentioned arguments about the impact of the new UEFA regulation on clubs' incentives to report more predictable earnings figures (based on cash flows) thus enhancing earnings persistence.

Table 5. Results on the persistence of accruals and cash flows.

\begin{tabular}{|c|c|c|}
\hline Variables & Coef. & $\begin{array}{c}T \text {-Test } \\
\text { ( } p \text {-Value) }\end{array}$ \\
\hline \multicolumn{3}{|c|}{ FULL SAMPLE } \\
\hline Constant & $-0.056^{* * *}$ & $\begin{array}{l}-2.52 \\
(0.012)\end{array}$ \\
\hline ROA & $0.162 * *$ & $\begin{array}{c}1.93 \\
(0.054)\end{array}$ \\
\hline TACC & 0.150 & $\begin{array}{c}1.26 \\
(0.210)\end{array}$ \\
\hline $\begin{array}{l}\mathrm{R}^{2} \text {-Adj. } \\
\text { F-stat }\end{array}$ & \multicolumn{2}{|c|}{0.416} \\
\hline
\end{tabular}


Table 5. Cont.

\begin{tabular}{|c|c|c|}
\hline Variables & Coef. & $\begin{array}{c}T \text {-Test } \\
(p \text {-Value) }\end{array}$ \\
\hline \multicolumn{3}{|l|}{ PRE-FFP } \\
\hline Constant & $-0.1061^{* * *}$ & $\begin{array}{c}-2.48 \\
(0.013)\end{array}$ \\
\hline $\mathrm{ROA}$ & 0.067 & $\begin{array}{c}0.66 \\
(0.512)\end{array}$ \\
\hline TACC & $0.270^{* *}$ & $\begin{array}{c}2.25 \\
(0.025)\end{array}$ \\
\hline $\mathrm{R}^{2}$-Adj. & \multicolumn{2}{|c|}{0.266} \\
\hline F-stat & $2.73^{* *}$ & $(0.06)$ \\
\hline \multicolumn{3}{|l|}{ POST-FFP } \\
\hline Constant & -0.042 & $\begin{array}{c}-1.57 \\
(0.117)\end{array}$ \\
\hline ROA & $0.288^{* *}$ & $\begin{array}{c}2.20 \\
(0.028)\end{array}$ \\
\hline TACC & 0.066 & $\begin{array}{c}0.45 \\
(0.655)\end{array}$ \\
\hline $\begin{array}{c}\mathrm{R}^{2} \text {-Adj. } \\
\text { F-stat }\end{array}$ & \multicolumn{2}{|c|}{0.791} \\
\hline
\end{tabular}

$* * *$ and ${ }^{* *}$ indicate statistical significance at the $1 \%$ and $5 \%$ significance level, respectively. The sample period includes fiscal years 2008-2016. The pre-FFP period is 2008-2011 and the post-FFP period is 2012-2016. ROA is the return on assets estimated as net income after tax to lagged total assets, and TACC is total accruals estimated as the difference between net income and operating cash flows divided by lagged total assets. Club fixed effects are included in the estimation.

Furthermore, to examine the validity of the third research hypothesis, we reestimated Models (1) and (2) between clubs belonging to the top European leagues and the rest, as well as also during the preand post-FFP periods. Results are presented in Table 6A. For both models, the persistence of the cash flow component of earnings (the coefficient on the ROA variable) is higher for clubs belonging to the minor leagues relative to clubs from major European leagues. Practically, results of Model (2) indicate that smaller clubs have $€ 0.34$ of current earnings persisting in the following year, relative to $€ 0.11$ for larger clubs. This evidence combined with the fact that accruals are more significant determinants of future earnings only for larger clubs verifies the third research hypothesis and indicates that clubs from smaller leagues are expected to report more persistent earnings figures to enhance their reliability towards the financial control body and also their chances to adhere to the new regulatory requirements. Put differently, since clubs from larger leagues gain a significant percentage of their annual budget (and revenues) from UEFA prizes, they are not so dependent on this type of financing, since they already present a balance between revenues from the league and UEFA prizes (Menary 2016).

Table $6 \mathrm{~B}$ presents the results regarding the impact of FFP regulation on earnings persistence between major and minor leagues. The results seem to corroborate the findings in Table 6 $\mathrm{A}$ and the main conclusions. Specifically, earnings persistence has decreased for the major leagues after the FFP initiation since the relative coefficient on ROA is statistically insignificant. On the one hand, the relative coefficient for clubs on the minor leagues has increased for the post-FFP period to 0.439 from 0.372 during the pre-FFP period. The same conclusion can be drawn by the estimation of Model (2) where TACC is only significant for the major league clubs but insignificant for minor leagues clubs. Overall, evidence in Table $6 \mathrm{~B}$ verifies the third research hypothesis and indicates that clubs from smaller leagues are expected to report more persistent earnings figures to enhance their reliability towards the financial control body to conform to the new regulatory requirements. 
Table 6. Results of the persistence of accruals and cash flows between major and minor European leagues and during the pre and post FFP periods. (A) Panel A: Overall estimation between major and minor leagues; (B) Panel B: Results between major and minor leagues during the pre and post FFP periods.

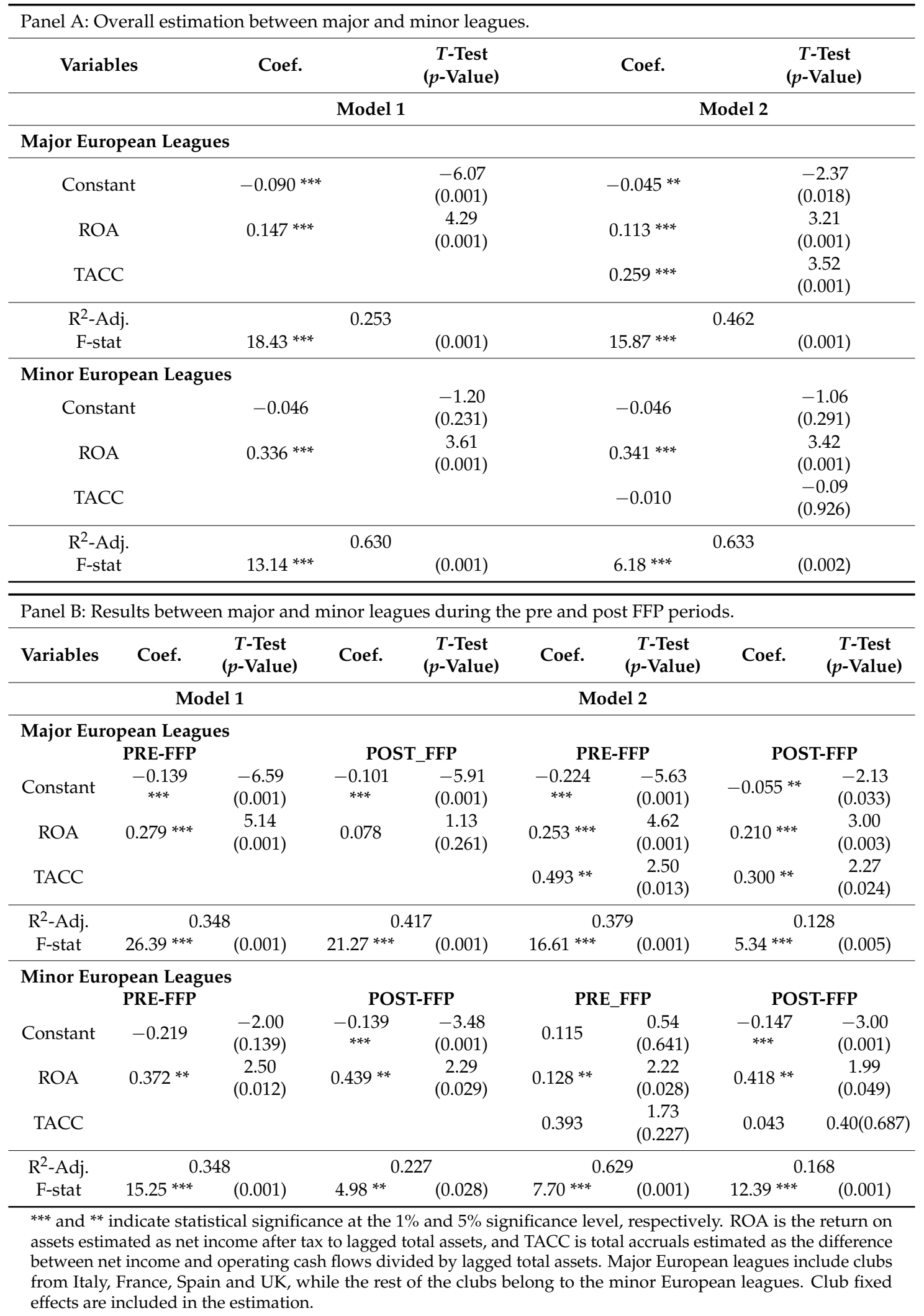


Finally, to check for the sensitivity of the main findings, we performed some robustness tests regarding the definition of the variables and the period under study. First, we re-estimated all models by estimating TACC based on two different definitions. The first is the difference between net income and overall cash flow (instead of operating cash flow) and the second is the balance sheet approach proposed by Ball and Shivakumar (2006) where TACC is estimated as the change in current assets minus change in current liabilities minus depreciation. Both alternative estimations yielded qualitatively similar results as those presented on Tables 3-6. In addition, all models were re-estimated by calculating ROA using net income before tax, but we observed no change in the main findings. In addition, we considered the case that, even though FFP regulation started in full effect from the 2012 fiscal year, several clubs could have been adjusting their financial reporting practices prior to that year. Thus, all models were re-estimated by defining the post-FFP period from 2011 to 2016. Empirical evidence indicated that the cash flow component of earnings was more significant than the accrual component of earnings after the FFP inauguration, thus verifying $\mathrm{H} 2$ and corroborating the robustness of our main results presented in Tables 3 and 5. Finally, we controlled for the potential impact of club's on-field success on their earnings persistence, since success on the field can be a driver of profitability. For this reason, we re-estimated both models by including their percentages of wins for every season as an additional control variable. Empirical evidence remained qualitatively unchanged from this test.

\section{Conclusions}

The present study investigated the issue of earnings persistence and predictability within a sample of European football clubs and whether the UEFA's new FFP regulation had any impact on the persistence of accruals and cash flow components of earnings. The analysis over the period 2008-2016 indicated that the cash flow component of earnings is more useful in predicting future earnings compared to accruals. This positive impact of cash flows for earnings prediction is more significant after the FFP regulation implementation because earnings predictability increased during that period. Moreover, the abovementioned finding is more significant for the smaller league clubs rather than the Top-5 league clubs. This finding is attributed to the fact that smaller league clubs are more in need of UEFA prize money relative to Big-5 league clubs (Menary 2016) because UEFA prize money constitutes a larger part of their annual revenues, thus they are more incentivized to produce a more predictable earnings stream.

In total, the empirical evidence from this study (within a services industry, i.e. football) seems to corroborate previous studies on the impact of financial regulation on the motivation of firms to improve or not the quality of their financial reporting. The examples of FDICIA, the Sarbanes-Oxley Act (SOX), and the compulsory implementation of IFRS in the European Union are characteristic cases where new regulation lead to an improvement of financial reporting (LaFond and You 2010; Barth et al. 2008; Doyle et al. 2007). The UEFA FFP regulation serves as a natural experiment on this study, since it shares several common characteristics with some of the abovementioned regulations: it forced clubs to report a larger amount of financial information, it introduced stricter control and monitoring on clubs' fundamentals and posed significant sanctions on clubs failing to fully conform to this regulation. Therefore, this paper provides an additional perspective on the debate regarding regulation and earnings persistence.

The findings of this study can provide useful implications for regulators since they indicate that, on average, football clubs report more predictable earnings streams after the new regulation initiation. Whether this is a secondary goal of the FFP (or a byproduct of the main goals of FFP regulation) is an issue for potential future exploration. As LaFond and You (2010) argued, regulation and control mechanisms in corporations cannot prevent bad decisions. Although is more difficult to make bad decisions under stricter financial regulation (due to enhanced control and strict sanctions), stricter regulation cannot prevent fraud or manipulation. Most times, regulation may lead human behavior in the opposite direction and efforts to circumvent regulation (Dimitropoulos et al. 2016). Thus, future research can extend current evidence by examining clubs' ownership and corporate 
governance structure as additional determinants of earnings persistence and how FFP regulation impacted that relation. Moreover, it would be interesting to examine the potential impact of different revenues sources (broadcasting, match day, UEFA prizes, etc.) on earnings persistence and the impact of sponsorship deals on the predictability of clubs' revenues and earnings streams. In addition, another avenue for future research is the examination of the impact of earnings persistence on clubs' cost of debt (or financing) and whether clubs with higher quality financial statements are compensated by investors.

Acknowledgments: We would like to thank the editor and two anonymous reviewers for helpful comments and suggestions that improved the paper significantly. Remaining errors and omissions are authors' responsibility. No research funding was provided to the authors by any source.

Author Contributions: Authors equally contributed to the research and writing of the paper.

Conflicts of Interest: The authors declare no conflict of interest.

\section{References}

Altamuro, Jennifer, and Anne Beatty. 2010. How does internal control regulation affect financial reporting? Journal of Accounting and Economics 49: 58-74. [CrossRef]

Andreff, Wladimir. 2007. French football: A financial crisis rooted in weak governance. Journal of Sports Economics 8: 652-61. [CrossRef]

Ball, Ray, and Lakshmanan Shivakumar. 2006. The Role of Accruals in Asymmetrically Timely Gain and Loss Recognition. Journal of Accounting Research 44: 207-42. [CrossRef]

Barth, Mary, Wayne. R. Landsman, and Mark H. Lang. 2008. International accounting standards and accounting quality. Journal of Accounting Research 46: 467-98. [CrossRef]

Cordery, Carolyn J., Dalice Sim, and Rachel F. Baskerville. 2013. Three models, one goal: Assessing financial vulnerability in New Zealand amateur sports clubs. Sport Management Review 16: 186-99. [CrossRef]

Dermit-Richard, Nadine, Nicolas Scelles, and Stephen Morrow. 2017. French DNCG management control versus UEFA Financial Fair Play: a divergent conception of financial regulation objectives. Soccer and Society. [CrossRef]

Dimitropoulos, Panagiotis, Stergios Leventis, and Emmanouil Dedoulis. 2016. Managing the European football industry: UEFA's regulatory intervention and the impact on accounting quality. European Sport Management Quarterly 16: 459-86. [CrossRef]

Doyle, Jeffrey, Weili Ge, and Sarah McVay. 2007. Determinants of weaknesses in internal control over financial reporting and the implications for earnings quality. Journal of Accounting and Economics 44: 193-223. [CrossRef]

Francis, Jennifer, Ryan LaFond, Per M. Olsson, and Katherine Schipper. 2004. Costs of equity and earnings attributes. The Accounting Review 79: 967-1010. [CrossRef]

Gaio, Cristina. 2010. The relative importance of firm and country characteristics for earnings quality around the world. European Accounting Review 19: 693-738. [CrossRef]

Jeon, Sungil, Joungman Kim, and Sangjae Lee. 2006. The persistence of abnormal earnings and systematic risk. Tourism Management 27: 867-73. [CrossRef]

Kang, Tony, Gopal V. Krishnan, Michael C. Wolfe, and Han S. Yi. 2012. The impact of eliminating the 20-F reconciliation requirement for IFRS filers on earnings persistence and information uncertainty. Accounting Horizons 26: 741-65. [CrossRef]

Kormendi, Rogen, and Robert Lipe. 1987. Earnings innovations, earnings persistence and stock returns. Journal of Business 60: 323-45. [CrossRef]

Kothari, S.P., Li Xu, and James E. Short. 2009. The effect of disclosures by management, analysts, and business press on cost of capital, return volatility, and analysts forecasts: a study using content analysis. The Accounting Review 84: 1639-70. [CrossRef]

Kousenidis, Dimitrios V., Anestic C. Ladas, and Christos I. Negakis. 2013. The effects of the European debt crisis on earnings quality. International Review of Financial Analysis 30: 351-62. [CrossRef]

KPMG. 2017. Broadcasting Revenue Distribution: Fine-Tuning the Balance. Available online: www.footballbenchmark. com/broadcasting_revenue_distribution (accessed on 27 March 2018). 
LaFond, Ryan, and Haifeng You. 2010. The federal deposit insurance corporation improvement act, bank internal controls and financial reporting quality. Journal of Accounting and Economics 49: 75-83. [CrossRef]

Menary, Steve. 2016. One rule for one: the impact of Champions League prize money and Financial Fair Play at the bottom of the European club game. Soccer and Society 17: 666-79. [CrossRef]

Mourao, Paulo. 2012. The indebtedness of Portuguese soccer teams - looking for determinants. Journal of Sports Sciences 30: 1025-35. [CrossRef] [PubMed]

Nicoliello, Mario, and Davide Zampatti. 2016. Football clubs' profitability after the Financial Fair Play regulation: Evidence from Italy. Sport, Business and Management: An International Journal 6: 460-75. [CrossRef]

Oei, Rosalyn, Alan Ramsay, and Paul Mather. 2008. Earnings persistence, accruals and managerial share ownership. Accounting and Finance 48: 475-502. [CrossRef]

Rascher, Daniel A., Matthew T. Brown, Mark S. Nagel, and Chad D. McEvoy. 2012. Financial risk management: The role of a new stadium in minimizing the variation in franchise revenues. Journal of Sports Economics 13: 431-50. [CrossRef]

Richardson, Scott A., Richard G. Sloan, Mark T. Soliman, and Irem Tuna. 2005. Accrual reliability, earnings persistence and stock returns. Journal of Accounting and Economics 39: 437-85. [CrossRef]

Rohde, Marc, and Christoph Breuer. 2016. Europe's elite football: Financial growth, sporting success, transfer investment and private majority investors. International Journal of Financial Studies 4: 12. [CrossRef]

Sloan, Richard G. 1996. Do stock prices fully reflect information in accruals and cash flows about future earnings? The Accounting Review 71: 289-315.

Solberg, Harry Arne, and Kjetil K. Haugen. 2010. European club football: Why enormous revenues are not enough? Sport in Society 13: 329-43. [CrossRef]

(C) 2018 by the authors. Licensee MDPI, Basel, Switzerland. This article is an open access article distributed under the terms and conditions of the Creative Commons Attribution (CC BY) license (http:// creativecommons.org/licenses/by/4.0/). 